\title{
Effect of seed density and sediment nutrient heterogeneity on recruitment and early patch growth in the seagrass Cymodocea nodosa
}

\author{
E. Balestri*, F. Vallerini, C. Lardicci \\ Dipartimento di Biologia, Unità di Ecologia e Biologia Marina, Pisa University, Pisa 56123, Italy
}

\begin{abstract}
Two mesocosm experiments were performed to examine the effects of seed density and small-scale nutrient heterogeneity on seedling recruitment and early development of patches of Cymodocea nodosa. In the first experiment, seeds were sown at 4 densities selected after determining mean natural density of seeds in the field, and the emergence and survival rates of seedlings were monitored for $1 \mathrm{yr}$. In the second experiment, seedlings were grown individually for $2 \mathrm{yr}$, either on substrate made heterogeneous or homogeneous with the addition of a fertiliser or on unfertilised substrate. The emergence rate and proportional survival of seedlings decreased significantly with increasing seed density. Seedlings grown on fertilised substrates were able to form patches, while those grown on unfertilised substrate failed to branch, providing experimental evidence of the role of nutrient limitation as a constraint for patch initiation. The size of seed-generated patches was significantly larger (in terms of total length of the rhizome network and number of shoots) on heterogeneous substrate than on homogeneous substrate at the same overall level of nutrient supply. Apparently, no preferential proliferation of shoots and branches occurred in the nutrient-rich half of the heterogeneous substrate. The results support our hypothesis that negative density dependence at the seed-seedling stage plays an important role in regulating population size. They also reveal that seedlings experiencing nutrient heterogeneity are capable of exploiting resources more efficiently than those in homogeneous environments, but are probably unable to escape from unfavourable patches or to select favourable ones, at least at the scale examined here.
\end{abstract}

KEY WORDS: Cymodocea nodosa · Seed · Density dependence · Recruitment · Nutrient heterogeneity $\cdot$ Patch growth $\cdot$ Clonal plants $\cdot$ Seagrass

\section{INTRODUCTION}

The seagrass Cymodocea nodosa (Ucria) Ascherson forms extensive meadows composed of multiple coalescent patches in shallow, sheltered to semi-exposed sites of the Mediterranean and Atlantic coasts (Vidondo et al. 1997, Green \& Short 2003). In many localities, C. nodosa populations are threatened by large-scale declines (Hemminga \& Duarte 2000, Meinesz et al. 2005), and efforts are underway to prevent further losses and to restore disturbed populations (Duarte 2000, Balestri \& Cinelli 2001, Curiel et al. 2003, Meinesz et al. 2005, Ruiz de la Rosa et al. 2006). A number of studies have shown that recruitment from seed plays a major role in the formation of new patches, maintenance of populations and recovery after disturbance (Duarte \& Sand-Jensen 1990a,b, Terrados 1993, Vidondo et al. 1997). However, little is known about the factors that regulate recruitment and growth of newly established patches. This information is of pivotal importance because it can facilitate the incorporation of seeds in restoration programmes and enable prediction of the extension of new clones in space.

Studies have shown that this species produces a large amount of seeds annually. In summer, mature seeds are buried in the sediment around the base of maternal shoots where they remain in a state of en- 
forced dormancy induced by temperature and salinity conditions (Caye et al. 1992), although some seeds may be transported by water to other places (Caye \& Meinesz 1985, Buia \& Mazzella 1991, Caye et al. 1992). Approximately $50 \%$ of the seeds entering the sediment germinate the following spring, in accordance with the seasonal environmental conditions (Caye \& Meinesz 1986, Pirc et al. 1986). The remaining seeds may persist in a sediment seed bank for some years, reaching densities of up to $1378 \mathrm{~m}^{-2}$ (Terrados 1993, Reyes et al. 1995, Cancemi et al. 2002). It has been estimated that only a few $(<10 \%)$ of the seedlings that emerge annually survive to their first year and initiate a new patch through clonal growth (Vidondo et al. 1997, Duarte \& Sand-Jensen 1990a). A number of factors have been proposed for such relatively low survival rates, including physical disturbance and nutrient limitation (Duarte \& Sand-Jensen 1996, Vidondo et al. 1997), but the possible importance of biotic factors such as seed density has largely been ignored. It has been demonstrated that in some terrestrial plants the chance of a seed becoming an established seedling may greatly decrease with increasing density of neighbouring seeds or just-emerged seedlings. This negative relationship has been related to the existence of mechanisms of intra-specific competition through interference or exploitation of essential resources such as nutrients and space (Palmblad 1968, Linhart 1976, Murray 1998, Goldberg et al. 2001). Density dependence, acting at the establishment stage, may play a critical role in determining the number of new individuals entering a population and, therefore, constitute an important system of regulation of the size of natural populations (Miller et al. 1994, Murray 1998, Silva Matos et al. 1999, Tielbörger \& Prasse 2009). Existing publications provide very limited information about the role of seed density in affecting recruitment by seed in seagrasses. In the few species tested for density dependence, no consistent effects of seed density on germination or emergence have been detected (Orth et al. 2003), but negative effects on early seedling growth and survival have been reported (Granger et al. 2000, Balestri \& Lardicci 2008).

After successful seedling establishment, the growth and architecture of a new Cymodocea nodosa patch is explained by simple growth rules (rhizome elongation and branching rates, branching angle and spacer length), and is probably affected by environmental signals including nutrients (Duarte \& Sand-Jensen 1990a, 1996, Perez et al. 1994, Sintes et al. 2005). In natural environments, nutrients are often distributed unevenly in space, and there is evidence that physiological integration among interconnected ramets metres apart allows established $C$. nodosa clones to buffer against the effects of habitat heterogeneity (Terrados et al.
1997). Some studies have emphasised the importance of nutrient limitation at the seedling stage in constraining patch initiation (Duarte \& Sand-Jensen 1996, Nielsen \& Pedersen 2000). To our knowledge, no experimental studies have been performed to investigate the consequences of small-scale variation in nutrient availability for the horizontal growth of newly established clones. It is known that resource heterogeneity can affect plant growth at very small spatial scales (Wijesinghe \& Hutchings 1997, Hutchings \& Wijesinghe 2008). Some terrestrial plants can achieve greater yield when growing on heterogeneous than on homogeneous substrate even if total nutrient quantity is invariant, since ramets in resource-rich microsites have the capacity to provide excess resources to ramets in resource-poor microsites (Alpert \& Mooney 1986, Slade \& Hutchings 1987a, Hutchings \& de Kroon 1994, Stuefer et al. 1994, Hutchings \& John 2004, Hutchings \& Wijesinghe 2008). Other plants can also increase the acquisition of nutrients in resource-rich patches by altering their growth patterns so as to invest the greatest proportion of their biomass in these patches (a manifestation of foraging behaviour; Hutchings \& de Kroon 1994) and thereby to escape from resource-poor patches (Salzman 1985, Slade \& Hutchings 1987b, Birch \& Hutchings 1994, Robinson 1994, Wijesinghe \& Hutchings 1996, 1997, Alpert \& Stuefer 1997). Seagrasses have the potential to exhibit foraging behaviour and morphological plasticity in response to environmental heterogeneity (Tomasko \& Dawes 1989, Perez et al. 1994, Marbà \& Duarte 1998, Jensen \& Bell 2001, Balestri et al. 2003, Kendrick et al. 2005, Schwarzschild \& Zieman 2008), but experimental evidence for foraging is still lacking.

The objectives of the present study were to test whether (1) initial seed density influences recruitment and initial survival of seedlings, and (2) small-scale heterogeneity in nutrient distribution affects the performance of newly established clones of Cymodocea nodosa. To this end, 2 mesocosm experiments were conducted. In the first experiment, seeds were sown at a range of densities below and above the mean natural field density and monitored for $1 \mathrm{yr}$ for seedling emergence, survival and growth. We hypothesised that both the emergence and the survival of seedlings would decrease with increasing seed density. In the second experiment, the growth and architecture of seedlings grown in homogeneous nutrient versus heterogeneous nutrient substrate, but the same overall amount of fertiliser, were examined over 2 yr. Based on clonal plant foraging theory we hypothesised that clone size would be larger on heterogeneous substrate than on homogenous substrate, and there would be a preferential placement of rhizomes into the nutrient-rich patch on heterogeneous substrate. 


\section{MATERIALS AND METHODS}

In early August 2005, 40 seed bank samples were randomly collected within a shallow Cymodocea nodosa meadow near Livorno, Italy $\left(43^{\circ} 30^{\prime} \mathrm{N}\right.$, $10^{\circ} 19^{\prime} \mathrm{E}$ ) at a depth of ca. $1 \mathrm{~m}$. In this area, the species shows a clear unimodal annual growth cycle typical of other Mediterranean locations, with a peak during June and July, and a cessation of rhizome growth from October to January (Terrados \& Ros 1992, Vallerini \& Balestri 2006). Sea surface water temperatures varied from about $12^{\circ} \mathrm{C}$ in winter to $27^{\circ} \mathrm{C}$ in summer and salinity ranged from 37.5 to 38 . The sediment was primarily fine sand of low organic content (1 to $2 \%$ ). The seed bank samples were obtained from the bottom by extracting forty $25 \times 25 \times 20 \mathrm{~cm}$ sediment sods. The samples were stored in natural seawater (38 salinity) and transported to the laboratory where seeds were separated from the sediment using a $2 \mathrm{~mm}$ mesh sieve. The number of seeds in each sample was counted in order to determine natural total seed bank density (i.e. the mean number of seeds $\mathrm{m}^{-2}$ ). Only the youngest cohort, i.e. seeds resulting from the current year's production, was used in this study in order to avoid potential differences in seed vigour due to ageing. Young seeds were distinguished from those of the previous generations by selecting only seeds that were still attached to maternal shoots at the time of collection. These seeds were planted at a depth of $2 \mathrm{~cm}$ in a large box filled with the sieved sediment. The box was placed in an outdoor mesocosm under conditions of ambient light and temperature for seed overwintering. The mesocosm consisted of a $5000 \mathrm{l}$ outdoor tank, equipped following a protocol previously established for the cultivation of Posidonia oceanica seeds (C. Lardicci \& E. Balestri unpubl.; Patent PI/2005/A/000092, $17 / 08 / 2005)$, and connected to a system that continuously pumped natural seawater from near the collection site. Daily measurement of seawater temperature and salinity demonstrated that these parameters were close to those recorded in the field.

Effects of initial seed density on seedling emergence and first year survival. In February 2006, young seeds were retrieved from the sandbox and planted into plastic pots $(45 \times 15 \mathrm{~cm})$ filled with fresh surface sediment ( $5 \mathrm{~cm}$ deep) collected near the sampling site at 4 different densities. The densities used were 3,15 , 30 and 45 seeds per pot, equivalent to ca. $0.1 \times, 0.5 \times, 1 \times$ and $1.5 \times$ the mean total seed bank density for the field. The seeds were spread uniformly across the sediment surface in each pot and then covered by $2 \mathrm{~cm}$ of fresh sediment derived from the process described in the previous paragraph. There were 2 replicate pots per seed density level. Before sowing, the sediment was sieved with a $2 \mathrm{~mm}$ mesh to remove any seeds poten- tially present and then homogenised by hand to reduce possible variations among experimental units. The pots were arranged randomly in the mesocosm at the same depth as seed collection (ca. $1 \mathrm{~m}$ ). The pots were re-allocated randomly within the tank and monitored every week for the emergence of the cotyledon. Counting continued until no further increases in emergence occurred in each pot.

The emergence rate was calculated by dividing the total number of emerged seedlings by the initial number of seeds sown in each pot. The time to emergence was calculated for each sample as follows:

$$
\text { time to emergence }=\Sigma(i \times n i) / \Sigma n i
$$

with $i$ the number of days since sowing and $n_{i}$ being the number of emerging seeds on Day $i$.

The proportion of surviving seedlings was calculated from the total number of seedlings in a pot recorded at the end of the first growing season (October 2006) and the number of emerged seedlings which emerged in that pot. The effects of seed density on the time to emergence, the rate of emergence and final proportion of surviving seedlings were tested with 1-way univariate analysis of variance (ANOVA). Density dependence was tested using nonlinear regression analysis with a power model which is predicted by the selfthinning law (Yoda et al. 1963). The emergence rate was regressed against initial seed density. The final proportion of surviving seedlings was regressed against initial seed density and against the number of emerging seedlings. All data were tested for normality (Lilliefor's test) and equality of variances (Bartlett's test).

Effects of nutrient distribution on the growth pattern of seed-generated clones. The experiment was designed to test for the potential effects of spatial heterogeneity in nutrient distribution on the development of young clones. As it would be difficult to measure and control for natural heterogeneity in the field, this study was conducted in a mesocosm with artificially imposed nutrient heterogeneity. Stored seeds were retrieved from the box in late February 2006 and germinated in boxes filled with sand collected in bare areas near the seed collection site. At this site, concentrations (means $\pm \mathrm{SD}$ ) of total nitrogen $(\mathrm{N})$ and total phosphorus (P) in the sand, measured with standard colorimetric methods (Kjeldhal and Olsen procedures) on triplicate samples collected with a core sampler $\left(0.0004 \mathrm{~m}^{2}\right)$ at a depth of $10 \mathrm{~cm}$, were $1.09 \pm 0.17$ and $0.002 \pm 0.0006 \mathrm{mg} \mathrm{g}^{-1}$ dry sand, respectively. At the end of May 2006, seedlings with no offspring ramets were selected for size (i.e. length of leaves) uniformity from the seedling stock and transferred to boxes $(55 \times$ $20 \mathrm{~cm}$, depth $20 \mathrm{~cm}$ ) containing fresh natural sand with or without added nutrients. The maximum leaf length of the selected seedlings was ca. $2 \mathrm{~cm}$, corresponding 
to the mean leaf length recorded in the seedling stock $(1.9 \pm 0.1 \mathrm{~cm}, \mathrm{n}=20)$ from the typical field conditions. Prior to use, each box was partitioned into 2 sections of the same size by a removable divider. The boxes were then assigned randomly to 3 treatments; heterogeneous nutrient distribution, homogenous nutrient distribution and no-nutrient addition. In the heterogeneous and homogenous treatments sand was enriched with same total quantity of a controlled-release fertiliser (Pluscote, $16 \% \mathrm{~N}, 8 \% \mathrm{P}_{2} 0,16 \% \mathrm{~K}_{2} 0$, formulated for a 6 mo release rate); only the distribution within the box differed. Prior to planting, the sand was sieved with a $2 \mathrm{~mm}$ mesh, washed with seawater, carefully mixed by hand and then distributed randomly in the boxes in order to minimise possible variations in sediment conditions among treatments. The boxes were left in the mesocosm for 2 wk before planting. Previous tests demonstrated that this procedure did not significantly influence sediment grain size, nutrient levels or organic matter content in comparison with ambient sediment, and there were also no significant differences in these variables among treatments (Bellone 2007). To create a patchy nutrient environment in the heterogeneous treatment (Het), one half of the box (nutrient-rich half) received the fertiliser at the manufacturer's recommended rate of $1.5 \mathrm{~g} \mathrm{l}^{-1}$ of sand (corresponding to a total amount of $10 \mathrm{~g}$ ) while the other (nutrient-poor half) received the fertiliser at half of the manufacturer's recommended rate $\left(0.75 \mathrm{~g} \mathrm{l}^{-1}\right.$ of sand, corresponding to a total amount of $5 \mathrm{~g}$ ). The total amount of fertiliser (15 g) was distributed evenly throughout the halves in the homogeneous treatment (Hom). This addition corresponded to a nutrient load of about $4 \mathrm{~g} \mathrm{~N} \mathrm{~m}^{-2} \mathrm{mo}^{-1}$ and $2 \mathrm{~g} \mathrm{P} \mathrm{m}^{-2} \mathrm{mo}^{-1}$, which was close to the levels of nutrients used to prevent nutrient limitation of the growth of this species (Duarte 1990, Perez et al. 1991). The no-addition treatment (No-ad) did not receive fertiliser and served as a control in which seedlings might experience nutrient-limiting conditions. There were 3 replicate boxes per treatment. Pluscote is similar to Osmocote ${ }^{\circledR}$, a coated fertiliser successfully used for long-term enrichment rates in marine sediments (Worm et al. 2000). Recent experiments have shown that the fertiliser pellets likely act as a localised point source of nutrients which are released at a constant rate into the sediment and pore water, and that they do not increase significantly in the water column (Olsen \& Valiela 2010). Our preliminary tests conducted in a mesocosm (at 17 to $19^{\circ} \mathrm{C}$ ) to examine the effective diffusion radius of fertilisation into the sand boxes $(n=2)$ revealed that 1 mo after addition of the fertiliser $(10 \mathrm{~g})$ to a sand area of $0.017 \mathrm{~cm}^{2}(15 \mathrm{~cm}$ diameter), the concentrations of total $\mathrm{N}$ and total $\mathrm{P}$ within this area $\left(1.24 \pm 0.005 \mathrm{mg} \mathrm{N} \mathrm{g}^{-1}\right.$ and $0.05 \pm 0.007$ mg $\mathrm{P} \mathrm{g}^{-1}$ dry sediment) were significantly higher than those ( $t$-test for independent samples, for $\mathrm{N}$ and $\mathrm{P}$, respectively: $t=4.6, \mathrm{p}=0.04 ; t=21.25, \mathrm{p}=0.002)$ in unfertilised sand boxes used as control $(0.91 \pm 0.05 \mathrm{mg}$ $\mathrm{N} \mathrm{g}^{-1}$ and $0.002 \pm 0.0003 \mathrm{mg} \mathrm{P} \mathrm{g}{ }^{-1}$ dry sediment). However, at a distance of $10 \mathrm{~cm}$ from the edge of the fertilised area the nutrient concentrations $(1.01 \pm 0.13 \mathrm{mg}$ $\mathrm{N} \mathrm{g}^{-1}$ and $0.003 \pm 0.0001 \mathrm{mg} \mathrm{P} \mathrm{g}^{-1}$ dry sediment) did not differ from those of the control ( $t$-test for independent samples, for $\mathrm{N}$ and $\mathrm{P}$, respectively: $t=0.59, \mathrm{p}=$ $0.61 ; t=3.4, \mathrm{p}=0.07$ ). As the length of each box half was about $20 \mathrm{~cm}$, nutrient heterogeneity was likely to persist in the heterogeneous treatment.

Seedlings were randomly assigned to the 3 treatments and a single seedling was planted in the exact centre of the box, at the junction between the 2 halves, giving each half cell an a priori equal chance of being colonised. The divider was removed after planting to allow offspring ramets to root freely within the box. The boxes were laid out in a fully randomised arrangement in the mesocosm and redistributed weekly to avoid any potential local position effect. At the end of the first growing season (October 2006), the growth characteristics of seedlings were recorded, while taking care not to disturb them. Since the rhizome was still poorly developed at this stage, only the number of shoots, the number of leaves per shoot and the length of the longest leaves of each seedling were measured. The seedlings were then allowed to continue growing for another season. In March 2007, the substrate in each treatment was enriched for a second time with Pluscote granules applied in the same fashion as the year before. At the end of the second growing season (October 2007), the substrate was removed from the rhizome of the plants to record the number and distribution of shoots and branches, the number of leaves per shoot, the length of the longest leaves, internodal length (spacer length) and total length of the rhizome network.

One-way multivariate analyses of variance (MANOVA) were performed to test for the effect of fertilisation on the whole-clone growth separately for each of the 2 growing seasons. This was followed by the corresponding ANOVA. Significant differences between means were determined using Fisher's least significant difference (LSD) multiple-means comparison tests at $\mathrm{p}<0.05$. Only rhizome length data were log transformed to correct for non-normality and heteroscedasticity. The preferential location of shoots and branches in the heterogeneous treatment at the end of the experiment was examined using the distribution of these structures in each of the 2 halves (nutrient-rich and nutrient-poor) of the box. The mean proportion of the total number of shoots and branches distributed in each of the 2 halves was compared to an expected value of $50 \%$ using the 1-sample $t$-test procedure. No significant deviation from $50 \%$ would indicate a random placement. 


\section{RESULTS}

\section{Effects of initial seed density on seedling emergence and survival}

The density of young seeds of Cymodocea nodosa varied between 0 and 224 seeds $\mathrm{m}^{-2}$ (average density \pm SE: $73.2 \pm 9.2$ seeds $\mathrm{m}^{-2}$ ) in the field. The total density of seeds in the seed bank varied from 16 to 1088 seeds $\mathrm{m}^{-2}$ (average density $329.6 \pm 49.9$ seeds $\mathrm{m}^{-2}$ ) and their distribution was highly skewed (skewness $=0.80$ ) (Fig. 1). Seedlings emerged in the mesocosm from Day 10 (February 2006) to Day 130 (June 2006) after planting (Fig. 2a). The time to emergence tended to increase at the lowest density (Fig. 2b), but the trend was not statistically significant $\left(F_{3,4}=0.87 ; \mathrm{p}=0.52\right)$. Overall, $56 \%$ of the planted seeds failed to germinate and $64 \%$ of emerged seedlings died during the first year. Seed density had a significant effect both on the emergence rate $\left(F_{3,4}=15.50, \mathrm{p}=0.01\right)$ and proportion surviving $\left(F_{3,4}=29.90 ; \mathrm{p}=0.003\right)$. Regression analysis indicated a negative relationship between seed density and emergence, suggesting negative density dependence (Fig. 3a). Regressions of the proportion surviving on seed density or number of emerging seedlings were also negative (Fig. $3 b, c)$.

\section{Effects of nutrient distribution on the growth pattern of seed-generated clones}

After emergence, seedlings produced at least 3 leaves on the primary shoot. At the end of the first growing season (October 2006), most seedlings (83\%) grown on fertilised substrates developed a plagiotropic rhizome and at least a new shoot. Shoot production



Fig. 1. Cymodocea nodosa. Frequency distribution of seeds in the natural seed bank
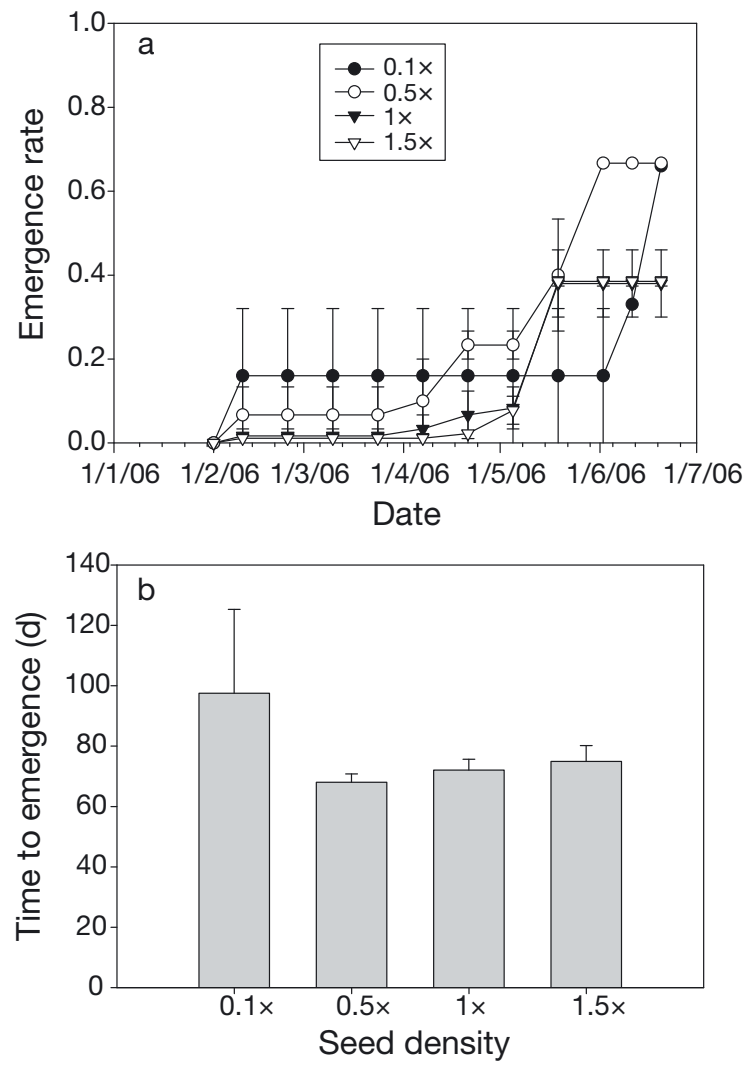

Fig. 2. Cymodocea nodosa. Effects of seed density $(0.1 \times, 0.5 \times$, $1 \times$ and $1.5 \times$ natural seed density) on (mean \pm SE) (a) emergence rate and (b) time to emergence. $\mathrm{n}=2$ pots per density. Dates are given as $\mathrm{d} / \mathrm{mo} / \mathrm{yr}$

was lower in seedlings in the unfertilised substrate. No branching was observed at this stage in any treatment. MANOVA revealed significant differences among treatments in the whole-seedling growth at the end of this season (Table 1). Seedlings produced on average a higher number of shoots and number of leaves per shoot on heterogeneous substrate than on homogeneous substrate or without fertiliser (Fig. 4a,b). The maximum leaf length was similar among treatments (Fig. 4c).

By the spring of the successive year (April 2007), fertilised seedlings started to produce new shoots and lateral (secondary and tertiary) rhizomes. The first lateral rhizome branch emerged from the primary rhizome after the production of 1 to 2 internodes and it spread in the opposite direction forming an angle between 150 and $180^{\circ} \mathrm{C}$, while the rest of the branches formed angles between 90 and $100^{\circ} \mathrm{C}$. Branching was slower in the unfertilised substrate. At the end of the second growing season (October 2007), seedlings had colonised most of the substrate surface within the boxes. MANOVA revealed significant differences among treatments in whole-clone growth (Table 2). 
More shoots were produced by seedlings grown on heterogeneous substrate than on homogeneous substrate or without fertiliser (Fig. 5a, Table 2). The total rhizome network tended to be greater in heterogeneous substrate, but the trend was not statistically
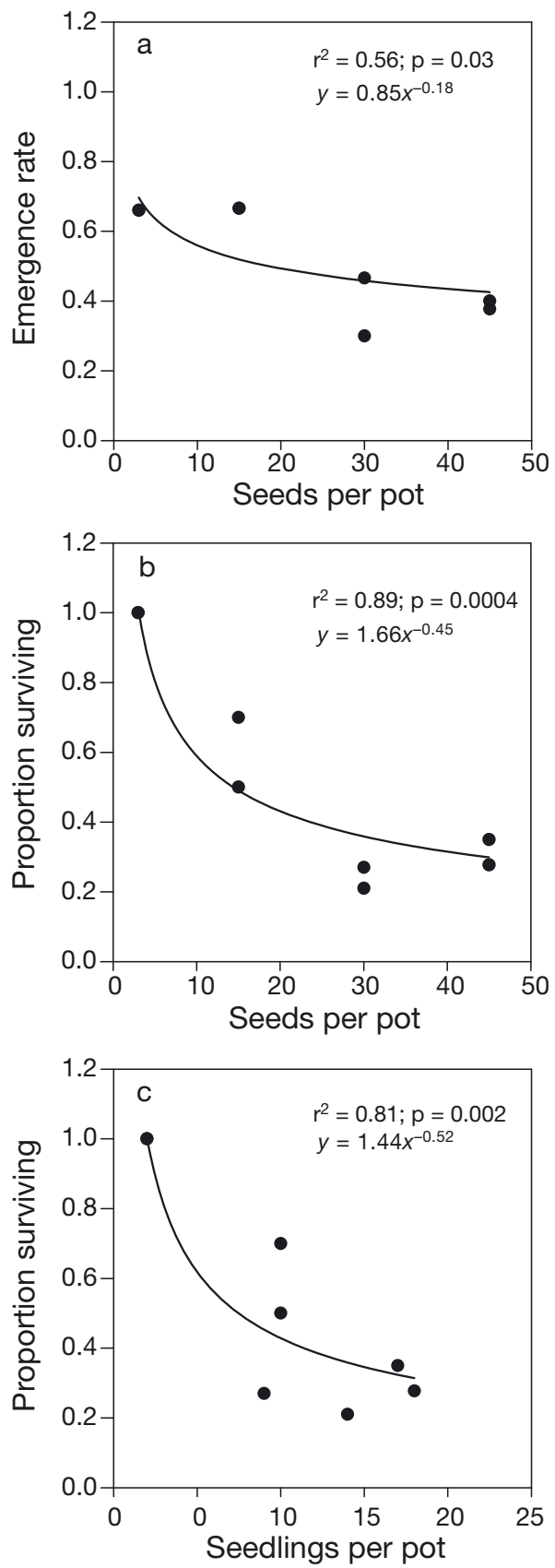

Fig. 3. Cymodocea nodosa. Effect of seed density on (a) the emergence rate calculated as the proportion of seeds that emerged based on total emergence and (b) the proportion surviving calculated as the number of surviving seedlings divided by sowing density. (c) Effect of the number of emerged seedlings on the proportion surviving. Regression coefficients, significance and equations of fitted curves are reported. $n=2$ pots per seed density significant (Fig. 5b, Table 2). There was no significant difference between heterogeneous and homogeneous treatments in the number of lateral rhizomes per seedling (Fig. 5c) or the mean length of internodes (Fig. 5d, Table 2). The maximum length and mean number of leaves per shoot varied from 7.4 to $10.6 \mathrm{~cm}$ and from 3.6 to 4.1 , respectively (Fig. 5e,f). Since these traits are not considered to be critical in foraging for nutrients (de Kroon \& Hutchings 1995), data were not included in the analysis. The mean proportion $( \pm \mathrm{SD})$ of

Table 1. Cymodocea nodosa. The effect of pattern of nutrient supply on the first-year growth of seedlings. The results of (a) 1-way multivariate analysis of variance with no. of shoots, mean number of leaves per shoot and maximum leaf length as dependent variables and pattern of nutrient supply $(P)$ as independent variable; and (b) the corresponding univariate analyses of variance. Wilks' lambda $(\lambda)$, the degree of freedom (df), $F$ statistic, Fisher's LSD test and significance (at $p<0.05$ ) are reported. Het: heterogeneous treatment; Hom: homogeneous treatment; No-ad: no addition treatment (control)

\begin{tabular}{|c|c|c|c|c|}
\hline (a) Source & $\lambda$ & df & $F$ & $\mathrm{p}$ \\
\hline $\begin{array}{l}\text { Pattern of nutri- } \\
\text { ent supply }(P)\end{array}$ & 0.04 & 6,8 & 5.31 & 0.01 \\
\hline (b) Variable & $\mathrm{df}$ & $F$ & $\mathrm{p}$ & Fisher's LSD \\
\hline No. of shoots & 2 & 28.0 & 0.0009 & Het $>$ Hom $>$ No-ad \\
\hline No. of leaves & 2 & 6.0 & 0.03 & $\begin{array}{l}\text { No hypothesis } \\
\text { alternative }\end{array}$ \\
\hline Max. leaf length & 2 & 2.58 & 0.15 & \\
\hline
\end{tabular}

Table 2. Cymodocea nodosa. The effect of pattern of nutrient supply on the second-year growth of seedlings. The results of (a) 1-way multivariate analysis of variance with no. of shoots, number of branches, internodal length and total length of the rhizome network as dependent variables and pattern of nutrient supply $(P)$ as independent variable; and (b) the corresponding univariate analyses of variance. Wilks' lambda $(\lambda)$, the degree of freedom (df), $F$ statistic, Fisher's LSD test and significance (at $\mathrm{p}<0.05$ ) are reported. Het: heterogeneous treatment; Hom: homogeneous treatment; No-ad: no addition treatment (control)

\begin{tabular}{|c|c|c|c|c|}
\hline (a) Source & $\lambda$ & df & $F$ & $\mathrm{p}$ \\
\hline $\begin{array}{l}\text { Pattern of nutri- } \\
\text { ent supply }(P)\end{array}$ & 0.02 & 8,6 & 4.6 & 0.03 \\
\hline (b) Variable & $\mathrm{df}$ & $F$ & $\mathrm{p}$ & Fisher's LSD \\
\hline No. of shoots & 2 & 17.35 & 0.003 & Het $>$ Hom $>$ No-ad \\
\hline No. of branches & 2 & 5.20 & 0.04 & Hom $=$ Het $>$ No-ad \\
\hline $\begin{array}{l}\text { Mean internodal } \\
\text { length }\end{array}$ & 2 & 15.08 & 0.004 & Hom $=$ Het $>$ No-ad \\
\hline Rhizome length & 2 & 31.79 & 0.0002 & Hom $=$ Het $>$ No-ad \\
\hline
\end{tabular}



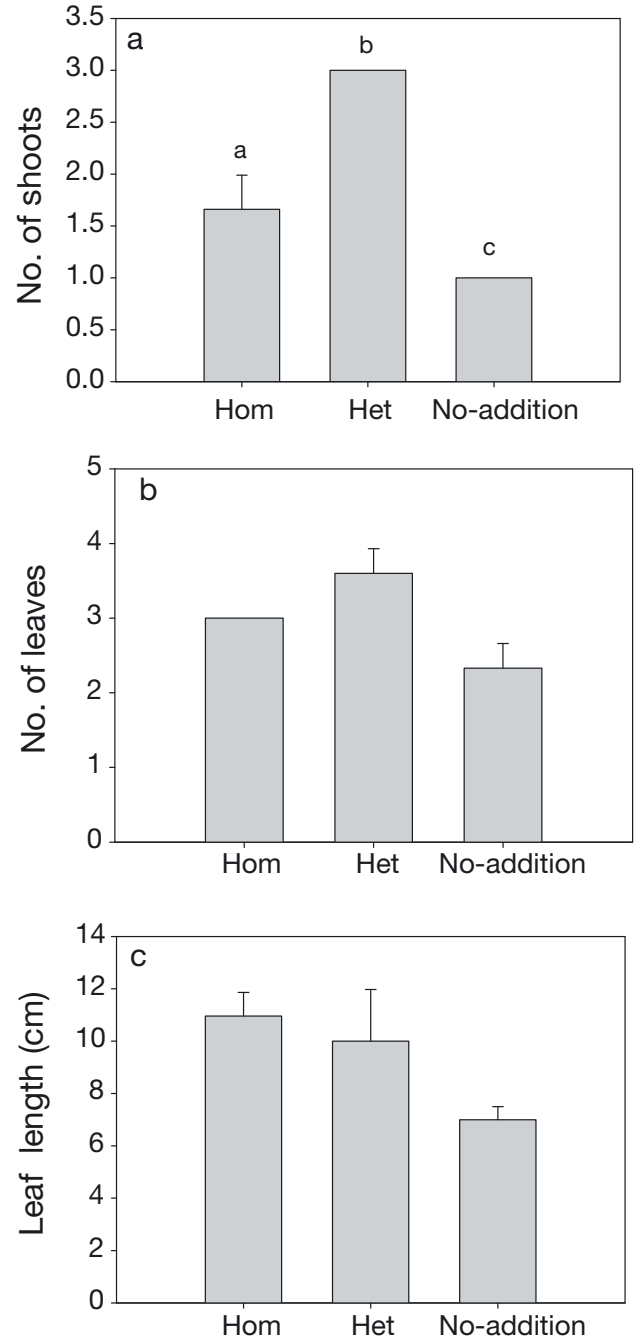

Fig. 4. Cymodocea nodosa. The effects of the different treatments, heterogeneous (Het), homogeneous (Hom) and unfertilised (No-addition), on morphological variables (mean $\pm \mathrm{SE}$ ) of first-year seedlings (October 2006); (a) number of shoots, (b) number of leaves per shoot and (c) maximum leaf length. Different letters above bars in (a) indicate statistically significant differences (Fisher's LSD multiple comparison test, $\alpha=$ 0.05). Hom: homogeneous treatment; Het: heterogeneous treatment; No-addition: no addition treatment (control); $\mathrm{n}=3$ boxes per treatment

branches ( $83 \pm 1.6 \%$ ) and shoots $(59 \pm 0.8 \%)$ placed by seedlings in the rich half of the heterogeneous substrate did not differ significantly from a value of $50 \%$ $(t=2, \mathrm{p}=0.18 ; t=1.13, \mathrm{p}=0.37)$ which is predicted by a random placement.

\section{DISCUSSION}

Previous studies have suggested that Cymodocea nodosa experiences negative density dependence dur- ing patch growth, because of strong competition among neighbouring shoots for limiting resources caused by local crowding (Duarte \& Sand-Jensen 1996). The present study shows that the probability of a seedling emerging and surviving decreases with increasing seed density, supporting the hypothesis that this species can also experience negative density dependence very early in its life history. The question that remains is whether the density dependence we observed is due to the effects of the seeds themselves or rather to the effects of newly emerging seedlings. Our estimates indicate that the probability that a seed will emerge decreases markedly (ca. 50\%) at a density of 30 seeds per experimental unit, which was equivalent to the average total density of the seed bank (320 seeds $\mathrm{m}^{-2}$ ), and the chance that an emerged seedling will survive to the first year is ca. $20 \%$. The density of only the youngest seed cohort was altered in this study. However, the relative density of these seeds in the field was low (ca. $20 \%$ ) in relation to the total seed bank density; thus the emergence rate of seedlings and their spatial distribution in natural populations could be strongly linked to the density of surviving ungerminated seeds from the previous year. Our estimates were only slightly higher than the annual emergence and survival rates recorded in the field by other authors (Duarte \& Sand Jensen 1990a, Vidondo et al. 1997). Therefore, seed density effects could explain a substantial fraction of patch initiation failure recorded in natural populations, and the remaining fraction could be attributed to the effects of environmental factors and possible restrictions imposed by the presence of adult shoots. Indeed, seedlings which emerge under the canopy of adults may simultaneously experience negative (shading and root competition) and positive (physical protection) interactions (Terrados 1993, Granger et al. 2000, Orth et al. 2006), but the net effect on seedling growth and survival could depend on the relative strength of the opposing interactions. Future studies should investigate the actual effects of competition by adults on seedling performance.

Another important aspect that deserves attention in the future is the physiological mechanism responsible for such density effects and its adaptive value. We speculate that genets coexisting under conditions of resource limitation may be competing with each other for access to nutrients or space and, therefore, negative density dependence could represent a mechanism to reduce the likelihood of intraspecific competition at higher densities and also ensure the persistence of a seed reservoir for about 2 yr (Caye et al. 1992). However, chemical interference cannot be excluded. The high mortality rate of seedlings could lead to the dominance of those individuals within the established meadows with most space. A number of studies on the 

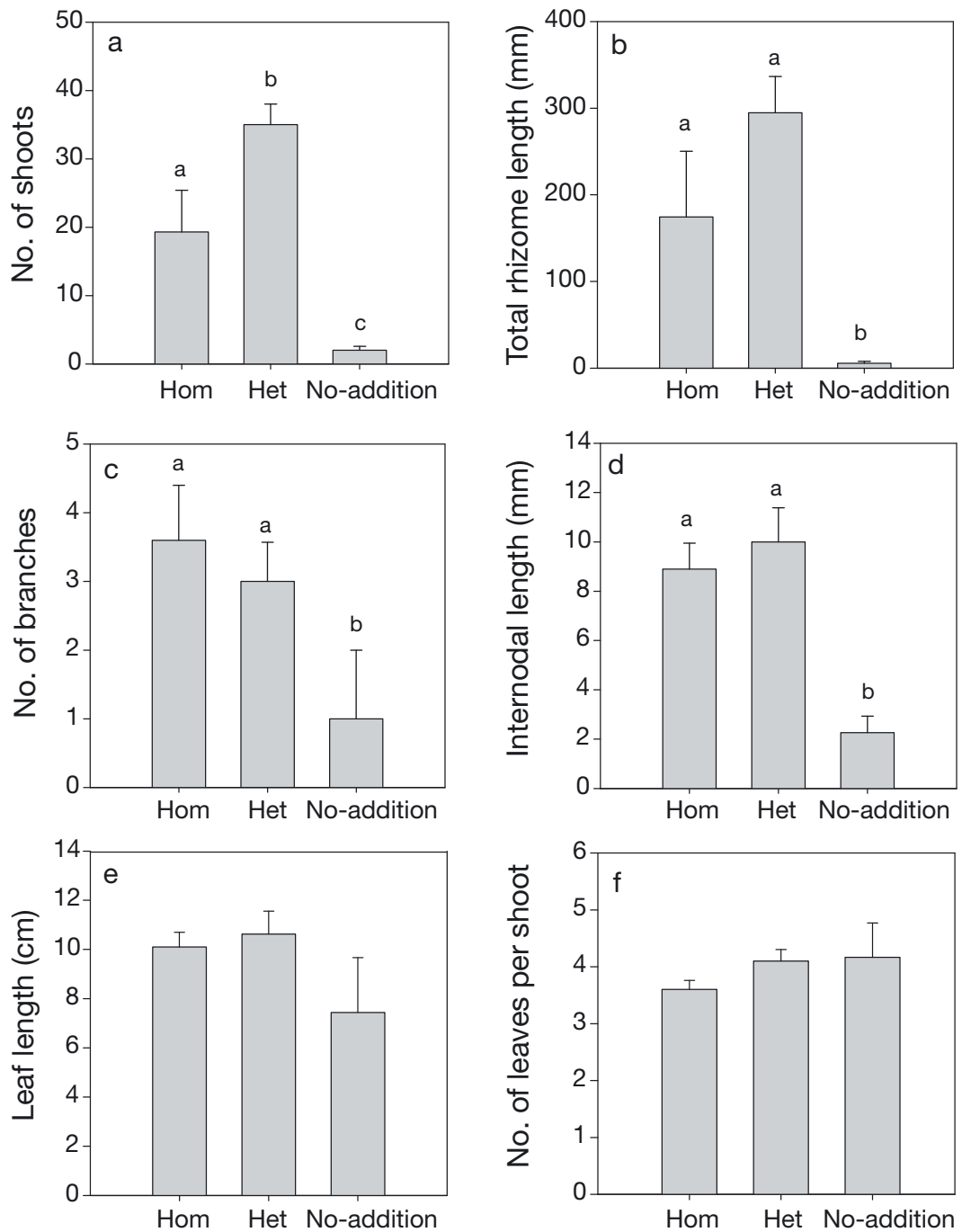

Fig. 5. Cymodocea nodosa. The effects of the different treatments, heterogeneous (Het), homogeneous (Hom) and unfertilised (No-addition), on morphological variables (mean \pm SE) of second-year seedlings (October 2007); (a) number of shoots, (b) total rhizome length, (c) number of branches, (d) internodal length, (e) maximum leaf length and (f) number of leaves per shoot. Different letters above bars indicate statistically significant differences (Fisher's LSD multiple comparison test, $\alpha=0.05)$. Hom: homogeneous treatment; Het: heterogeneous treatment; No-addition: no addition treatment (control) $; \mathrm{n}=3$ boxes per treatment

examine the responses of seedlings to the pattern of nutrient supply in seagrasses. Our results demonstrate that C. nodosa seedlings fail to branch in unfertilised substrate, but are able to produce new shoots and branches on fertilised substrates in their second year, confirming the role of nutrient limitation as a constraint to seedling growth (Duarte \& Sand-Jensen 1996, Nielsen \& Pedersen 2000). They also show that the overall growth of clones in heterogeneous substrate was ca. twice that in homogenous substrate, although the 2 types of substrates contained the same total amount of nutrients, and most of this growth was realised as proliferation of shoots. This finding suggests that the effectiveness of resource acquisition of young clones and their ability to colonise available space may depend on the quality, in terms of nutrient supply, of the habitat in their immediate neighbourhood. However, the results do not support our hypothesis of a preferential placement of shoots and lateral branches in nutrient-rich patches, as branches and shoots appeared to be evenly distributed throughout the heterogeneous substrate. Therefore, this species may not be effective at selective exploitation of favourable patches, at least at the life history stage and scale examined here, but rather makes use of them once they are encountered. Since ramets of a single seedling in the heterogeneous treatment were exposed simultaneously to different nutrient conditions (high and low), ramets located in the nutrient-rich half might have enhanced nutrient uptake and then redistributed them within the whole clone through physiological

nutrient content of seedlings of Cymodocea nodosa and other Mediterranean seagrasses have suggested that the availability of nutrients (nitrogen and phosphorus, in particular) may be an important constraint to the development of a new patch (Duarte 1990, Duarte \& Sand-Jensen 1996, Nielsen \& Pedersen 2000, Balestri et al. 2009). An experimental study has also demonstrated that the growth of adult C. nodosa patches is enhanced upon application of nutrients in the form of artificial fertilisers to sediment (Perez et al. 1991). To our knowledge, this is the first attempt to integration. The greater production of shoots exhibited by seedlings in the heterogeneous treatment might just be a result of the higher total amount of nutrients available in the sediment volume explored by a seedling in the heterogeneous than in the homogeneous treatment. It is important to note that many other clonal plants are unable to forage selectively for favourable patches within their environment because they lack the appropriate morphological plasticity, and this may permit a continuous search of habitat space by the plant (de Kroon \& Hutchings 1995). Additional 
research is required to fully understand how this species responds physiologically and morphologically to nutrient patches.

In conclusion, the present study reveals the importance of seed density dependence as a potential mechanism controlling recruitment in Cymodocea nodosa, and provides experimental evidence of the influence of nutrient availability and spatial distribution on the growth of newly established patches. This latest finding may add a new level of complexity to the process that shapes patch growth in natural environments (Kendrick et al. 2005). Hence, introducing the pattern of nutrients in the environment into the construction of models of $C$. nodosa patch development based on growth rules (Marbà \& Duarte 1998, Sintes et al. 2005) would allow a more realistic prediction of growth and space occupation. Such results may also be of practical value in designing effective restoration strategies, providing information on (1) the possible level of seed input required for achieving the highest rate of seedling establishment and (2) the pattern of fertiliser that could best support early patch growth.

Acknowledgements. We thank D. Bellone for technical assistance. We also thank F. Lenzi of the Mariculture Center of Rosignano Solvay (Leghorn, Italy) for providing facilities and technical support. Four anonymous referees provided constructive comments and helped to improve the manuscript.

\section{LITERATURE CITED}

Alpert P, Mooney HA (1986) Resource sharing among ramets in the clonal herb Fragaria chiloensis. Oecologia 70: 227-233

Alpert P, Stuefer JF (1997) Division of labour in clonal plants. In: de Kroon H, van Groenendael J (eds) The ecology and evolution of clonal plants. Backhuys, Leiden, p 137-154

Balestri E, Cinelli F (2001) Isolation and cell wall regeneration of protoplasts from Posidonia oceanica and Cymodocea nodosa. Aquat Bot 70:237-242

Balestri E, Lardicci C (2008) First evidence of a massive recruitment event in Posidonia oceanica: spatial variation in first-year seedling abundance on a heterogeneous substrate. Estuar Coast Shelf Sci 76:634-641

Balestri E, Cinelli F, Lardicci C (2003) Spatial variation in Posidonia oceanica structural, morphological and dynamic features in a northwestern Mediterranean coastal area: a multi-scale analysis. Mar Ecol Prog Ser 250:51-60

Balestri E, Gobert S, Lepoint G, Lardicci C (2009) Seed nutrient content and nutritional status of Posidonia oceanica seedlings in the northwestern Mediterranean Sea. Mar Ecol Prog Ser 388:99-109

Bellone D (2007) Accrescimento ed architettura di Cymodocea nodosa (Ucria) Ascherson: effetti di differenti fattori abiotici ed implicazione in interventi di restauro. MS dissertation, University of Pisa

Birch CPD, Hutchings MJ (1994) Exploitation of patchily distributed soil resources by the clonal herb Glechoma hederacea. J Ecol 82:653-664

Buia MC, Mazzella L (1991) Reproductive phenology of the
Mediterranean seagrasses Posidonia oceanica (L.) Delile, Cymodocea nodosa (Ucria) Aschers., and Zostera noltii Hornem. Aquat Bot 40:343-362

Cancemi G, Buia MC, Mazzella L (2002) Structure and growth dynamics of Cymodocea nodosa meadows. Sci Mar 66:365-373

Caye G, Meinesz A (1985) Observations on the vegetative development, flowering and seedling of Cymodocea nodosa (Ucria) Ascherson on the Mediterranean coasts of France. Aquat Bot 22:277-289

> Caye G, Meinesz A (1986) Experimental study of seed germination in the seagrass Cymodocea nodosa. Aquat Bot 26: $79-87$

Caye G, Bulard C, Meinesz A, Loquès F (1992) Dominant role of seawater osmotic pressure on germination in Cymodocea nodosa. Aquat Bot 42:187-193

Curiel D, Scarton F, Rismondo A, Marzocchi M (2003) Transplanting seagrasses in the Lagoon of Venice: results and perspectives. In: Ozhan E (ed) Proc 6th Int Conf Mediterr Coast Env. MED-COAST03, 2: 853-864

de Kroon H, Hutchings MJ (1995) Morphological plasticity in clonal plants: the foraging concept reconsidered. J Ecol 83:143-152

Duarte CM (1990) Seagrass nutrient content. Mar Ecol Prog Ser 67:201-207

Duarte CM (2000) The future of seagrass meadows. Environ Conserv 29:192-206

> Duarte CM, Sand-Jensen K (1990a) Seagrass colonization: patch formation and patch growth in Cymodocea nodosa patches. Mar Ecol Prog Ser 65:193-200

> Duarte CM, Sand-Jensen K (1990b) Seagrass colonization: biomass development and shoot demography in Cymodocea nodosa patches. Mar Ecol Prog Ser 67:97-103

> Duarte CM, Sand-Jensen K (1996) Nutrient constraints on establishment from seed and on vegetative expansion of the Mediterranean seagrass Cymodocea nodosa. Aquat Bot 54:279-286

> Goldberg DE, Turkington R, Olsvig-Whittaker L, Dyer A (2001) Density-dependence in an annual plant community: variation among life history stages. Ecol Monogr 71: 423-446

Granger SL, Traber MS, Nixon SW (2000) The influence of planting depth an density on germination and development of Zostera marina seeds. Biol Mar Mediterr 7:55-58

Green EP, Short FT (2003) World atlas of seagrasses. University of California Press, Berkeley, CA

Hemminga MA, Duarte CM (2000) Seagrass ecology. Cambridge University Press, Cambridge

Hutchings MJ, de Kroon H (1994) Foraging in plants: the role of morphological plasticity in resource acquisition. Adv Ecol Res 25:159-238

Hutchings MJ, John EA (2004) The effects of environmental heterogeneity on root growth and root/shoot partitioning. Ann Bot (Lond) 94:1-8

> Hutchings MJ, Wijesinghe D (2008) Performance of a clonal species in patchy environments: effects of environmental context on yield at local and whole-plant scales. Evol Ecol 22:313-324

Jensen S, Bell S (2001) Seagrass growth and patch dynamics: cross-scale morphological plasticity. Plant Ecol 155: 201-217

Kendrick GA, Duarte CM, Marbà N (2005) Clonality in seagrasses, emergent properties and seagrass landscapes. Mar Ecol Prog Ser 290:291-296

Linhart YB (1976) Density-dependent seed germination strategies in colonizing versus non colonizing plant species. J Ecol 64:375-380 
Marbà N, Duarte CM (1998) Rhizome elongation and seagrass clonal growth. Mar Ecol Prog Ser 174:269-280

Meinesz A, Javel F, Cottalorda JM, Thibaut T (2005) Disparition des phanérogames marines Cymodocea nodosa et Nanozostera noltii dans la lagune del l'Anse de Port-Cros (Var) et transplantation expérimentale de C. nodosa. Rapport GIS Posidonie. Laboratoire Environnement, Marin Littoral, Université de Nice-Sophia Antipolis, Nice, p 1-8

Miller TE, Winn AA, Schemske DW (1994) The effects of density and spatial distribution of seeds and seedlings on emergence time in Prunella vulgaris (Lamiaceae). Am J Bot 81:1-6

Murray BR (1998) Density-dependent germination and the role of seed leachate. Aust J Ecol 23:411-418

Nielsen SL, Pedersen MF (2000) Growth, photosynthesis and nutrient content of seedlings and mature plants of Cymodocea nodosa - the importance of clonal integration. Aquat Bot 68:265-271

Olsen YS, Valiela I (2010) Effect of sediment nutrient enrichment and grazing on turtle grass Thalassia testudinum in Jobos Bay, Puerto Rico. Est Coasts 33:769-783

Orth RJ, Fishman JR, Harwell MC, Marion SR (2003) Seeddensity effects on germination and initial seedling establishment in eelgrass Zostera marina in the Chesapeake Bay region. Mar Ecol Prog Ser 250:71-79

Orth RJ, Harwell MC, Inglis GJ (2006) Ecology of seagrass seeds and seagrass dispersal processes. In: Larkum AW, Orth RJ, Duarte MC (eds) Seagrasses: biology, ecology and conservation. Springer, Dordrecht, p 111-133

Palmblad I (1968) Competition in experimental populations of weeds with emphasis on the regulation of population size. Ecology 49:26-34

Perez M, Romero J, Duarte CM, Sand-Jensen K (1991) Phosphorus limitation of Cymodocea nodosa growth. Mar Biol 109:129-133

Perez M, Duarte CM, Romero J, Sand-Jensen K, Alcoverro T (1994) Growth plasticity in Cymodocea nodosa stands: the importance of nutrient supply. Aquat Bot 47:249-264

> Pirc H, Buia MC, Mazzella L (1986) Germination and seedling development of Cymodocea nodosa (Ucria) Ascherson under laboratory conditions and in 'situ'. Aquat Bot 26: 181-188

Reyes J, Sansón M, Afonoso-Carrillo J (1995) Distribution and reproductive phenology of the seagrass Cymodocea nodosa (Ucria) Ascherson in the Canary Islands. Aquat Bot 50:171-180

Robinson D (1994) The response of plants to non-uniform supplies of nutrients. New Phytol 127:635-674

Ruiz de la Rosa M, García N, Zarranz M, Manent P and others (2006) Preliminary results of experimental evaluation about different methods of transplanting Cymodocea nodosa in the Canary Islands. Biol Mar Mediterr 13:267-271

Salzman AG (1985) Habitat selection in a clonal plant. Science 228:603-604

Schwarzschild AC, Zieman JC (2008) Apical dominance and the importance of clonal integration to apical growth in

Editorial responsibility: Just Cebrian,

Dauphin Island, Alabama, USA the seagrass Syringodium filiforme. Mar Ecol Prog Ser 360:37-46

Silva Matos DM, Freckleton RP, Watkinson AR (1999) The role of density dependence in the population dynamics of a tropical palm. Ecology 80:2635-2650

Sintes T, Marbà N, Duarte CM, Kendrick GA (2005) Nonlinear processes in seagrass colonisation explained by simple clonal growth rules. Oikos 108:165-175

Slade AJ, Hutchings MJ (1987a) The effects of nutrient availability on foraging in the clonal herb Glechoma hederacea. J Ecol 75:95-112

Slade AJ, Hutchings MJ (1987b) Clonal integration and plasticity in foraging behaviour in Glechoma hederacea. J Ecol 75:1023-1036

Stuefer J, During HJ, de Kroon H (1994) High benefits of clonal integration in two stoloniferous species, in response to heterogeneous light environments. J Ecol 82:511-518

> Terrados J (1993) Sexual reproduction and seed banks of Cymodocea nodosa (Ucria) Ascherson meadows on the southeast Mediterranean coast of Spain. Aquat Bot 46: 293-299

Terrados J, Ros JD (1992) Growth and primary production of Cymodocea nodosa (Ucria) Ascherson in a Mediterranean coastal lagoon: the Mar Menor (SE Spain). Aquat Bot 43: $63-74$

Terrados J, Duarte CM, Kenworthy WJ (1997) Is the apical growth of Cymodocea nodosa dependent on clonal integration? Mar Ecol Prog Ser 158:103-110

> Tielbörger K, Prasse R (2009) Do seeds sense each other? Testing for density-dependent germination in desert perennial plants. Oikos 118:792-800

> Tomasko DA, Dawes CJ (1989) Evidence for physiological integration between shaded and unshaded short shoots of Thalassia testudinum. Mar Ecol Prog Ser 54:299-305

Vallerini F, Balestri E (2006) Spatial variations in vegetative and reproductive shoot density in two co-occurring Mediterranean seagrasses Cymodocea nodosa and Zostera noltii. Biol Mar Mediterr 13:97-101

> Vidondo B, Duarte CM, Middelboe AL, Stefansen K, Lützen T, Nielsen SL (1997) Dynamics of a landscape mosaic: size and age distributions, growth and demography of seagrass Cymodocea nodosa patches. Mar Ecol Prog Ser 158: 131-138

Wijesinghe DK, Hutchings MJ (1996) Consequences of patchy distribution of light for the growth of the clonal herb Glechoma hederacea. Oikos 77:137-145

Wijesinghe DK, Hutchings MJ (1997) The effects of spatial scale of environmental heterogeneity on the growth of a clonal plant: an experimental study with Glechoma hederacea. J Ecol 85:17-28

Worm B, Reusch TBH, Lotze HK (2000) In situ nutrient enrichment: methods for marine benthic ecology. Int Rev Hydrobiol 85:359-375

Yoda K, Kira T, Ogawa H, Hozumi K (1963) Self-thinning in overcrowded pure stands under cultivated and natural conditions. J Inst Polytech Osaka City Univ D14:107-129

Submitted: January 1, 2010; Accepted: August 23, 2010

Proofs received from author(s): October 11, 2010 